\title{
The role of traditional ecological knowledge in managing for biodiversity
}

\author{
by Charlene Higgins ${ }^{1}$
}

\section{The Brundtland Report and the Rio Conference}

The 1987 Report of the United Nations World Commission on Environment and Development, known as the Brundtland Report, recognized the important role of Indigenous peoples in sustainable development, and recommended that Indigenous peoples should be given a "decisive voice" in resource management decisions that affect them (World Commission on Environment and Development 1987). The Brundtland report pointed out that growing interaction of Indigenous communities with the larger world is increasing the vulnerability of these groups, since they are often left out of the processes of economic development. As a result, many Indigenous groups become dispossessed and marginalized, and their traditional practices disappear. The report acknowledged that these communities are repositories of vast accumulations of traditional knowledge and experience that link humanity with its ancient origins, and that their disappearance from the larger society is a loss because traditional knowledge has been used in the past to sustainably manage very complex ecological systems. The Brundtland report states that recognition and protection of traditional rights should be accompanied by measures to enhance the well-being of the community in ways appropriate to the group's lifestyle.

In June 1992, five years after the Brundtland Report was issued, the United Nations Conference on Environment and Development (UNCED) took place in Rio de Janeiro. The Rio Declaration stated that Indigenous peoples have a vital role in environmental management and development, that their knowledge and traditional practices clearly established the relevance of Indigenous peoples and the importance of protecting their rights in order to attain sustainable development. The Convention on Biological Diversity (CBD) was one of two legally-binding agreements opened for signature during the Summit. One objective of this agreement is to guide and govern the use of traditional knowledge and conservation of genetic resources, while protecting Indigenous peoples and local communities. The Government of Canada, with support of provincial and territorial governments, signed and ratified the United Nations Convention on Biological Diversity in 1992.

\section{The Convention on Biodiversity (Articles 8(j), 10(with), 17.2, 18.4)}

Managing for biodiversity is an inherent part of sustainable forest management. Sustainable forest management includes ecologically sound practices that maintain the forest ecosystems' integrity, productivity, resilience and biodiversity. There is increasing recognition that the use and application of traditional ecological knowledge and Indigenous natural resource management systems provide effective strategies for the sustainable use of natural resources (Posey 1996). The CBD

\footnotetext{
${ }^{1}$ Natural Resources Coordinator, Shuswap Nation Tribal Council, Kamloops, British Columbia V2H 1H1. e-mail: sntcnat@wkpowerlink.com.
}

highlights the value of working with Indigenous peoples on the conservation and sustainable use of biological diversity through information exchange (Article 17.2) and technology transfer (Article 18.4).

Although the whole Convention is of importance to Indigenous peoples, the key provisions are found in Articles 8(j) and 10(c). Article 8(j) requires that the traditional knowledge of Indigenous and local communities be respected, preserved and maintained; that the use of such knowledge should be promoted for wider application with the approval and involvement of the holders of such knowledge; and that they should equitably share in the benefits which arise from the use of their knowledge. The CBD also requires, in Article 10(c), that customary uses of biological resources in accordance with traditional cultural practices should be protected and encouraged. Canada played a lead role in drafting Article 8(j).

This paper discusses the role of traditional ecological knowledge in managing for biodiversity, and its use in sustainable resource management practices. To facilitate the implementation of the CBD in Canada, Indigenous peoples must be allowed to fully participate, and be included in development of guidelines, criteria and policies regarding sustainable resource use and management developed to implement the CBD in Canada. An objective of this paper is to promote the recognition and use of traditional ecological knowledge as an integral component of sustainable forest management practices. True recognition of traditional rights should take the form of a decisive voice from Indigenous communities regarding resource use in their traditional areas.

\section{Agenda 21}

In addition to adopting the CBD at the 1992 Rio de Janeiro Conference, participating governments, including Canada, adopted a program for action on implementing the concept of sustainable development as articulated in the Brundtland Report. This program was called Agenda 21. Agenda 21 includes a separate chapter on programs for Indigenous peoples, and calls on governments to fully include Indigenous peoples and their communities in resource use, decision making and management to ensure their rights are fully protected, and to reflect their values and traditional knowledge and practices in national policies and programs. Chapter 26 of Agenda 21 recognizes the traditional and direct dependence of Indigenous peoples on renewable resources, including sustainable harvesting, and how they are essential to the cultural, economic and physical well-being of Indigenous people and their communities.

Chapter 26 also discusses the role of Indigenous people and their communities. This chapter sites three main objectives:

a) The empowerment of Indigenous people and their communities; b) The strengthening of the active participation of Indigenous people and their communities in national policies, laws and programs for resource management; and,

c) The involvement of those people and communities in resource management and conservation strategies. 
Chapter 26 urges Governments to undertake a number of activities, including adopting laws to protect Indigenous intellectual and cultural property, helping to protect Indigenous lands from activities that are environmentally unsound, and developing national dispute-resolution systems.

Paragraph 11.12 calls for the adoption of national forest-management policies that "support the identity, culture and the rights of Indigenous people," (Barsh and Henderson 1997).

\section{Implementation of the Convention on Biodiversity (CBD) in Canada}

As soon as the CBD was ratified in Canada, an intergovernmental Biodiversity Working Group was established to develop a Canadian Biodiversity Strategy to meet the obligations of the $\mathrm{CBD}$ and enhance coordination of national efforts aimed at the conservation of biodiversity and sustainable use of biological resources. The responsibility for conserving biodiversity and ensuring sustainable use of biological resources is shared among provincial, territorial and federal governments. Canada has publicly supported the emergence of Indigenous peoples as a priority concern, and included Indigenous groups with representatives from other jurisdictions in the Biodiveristy Working Group. However, Canada has done little else in response to its obligations under the $\mathrm{CBD}$ towards empowering Indigenous peoples and ensuring their participation and involvement in the development of sustainable resource use, forestry practices and management.

The incorporation of traditional ecological knowledge into forest management practices can provide the framework needed by the government to implement the CBD. To meet the obligations of the CBD, the government of Canada must create the policy and research conditions that will lead to the conservation of biodiversity and the sustainable use of biological resources. In order to devise ways to implement the $\mathrm{CBD}$, adequate and effective legislation and policy must be in place as a framework for the provinces and territories to follow. One of the first steps towards this goal is a review and analysis of existing legislation to assess its limitations, and to better provide policy that directly incorporates the mandates laid out by Articles within the CBD, and ensures that the holders of traditional ecological knowledge benefit from its use. National and international mechanisms must also be in place with legal jurisdiction to deal with matters of redress, liability, restoration and compensation. Furthermore as specified by Article 16, national and international legislative, administrative and policy measures must be developed to protect intellectual property rights to Indigenous and traditional technologies.

Although British Columbia has developed legislation - the Forest Practices Code (FPC) - to manage and conserve biodiversity, it still assigns priority to maintaining timber production, and fails to address any of the objectives of Agenda 21, Chapter 26 described above. For example, the Forest Practices Code's Biodiversity Guidebook allows for the biodiversity requirements to be relaxed in situations where the AAC may be severely impacted (Ministry of Forests 1995). While the British Columbia government is completing an inventory of provincial ecosystems, the province is not providing the funding needed for First Nations communities to inventory and document traditional use and ecological knowledge. Under the $\mathrm{CBD}$, such knowledge must be preserved as an inherent component of biodiversity. Such baseline studies by First Nations and other Aboriginal communities are necessary to preserve, protect and incorporate this knowledge into resource use and management planning and policies. As long as legislative criteria and policies to manage the ecosystem are set by corporate-based industrial exploitation needs, the policies developed to protect biodiversity, promote and incorporate Aboriginal objectives and priorities, will be inadequate (M'Gonigle 1997).

The Leticia Declaration, produced in 1996 by the Intergovernmental Panel on Forests (IPF) working under the United Nations Commission on Sustainable Development outlined some general principles for the recognition of Indigenous rights and Indigenous participation in forest-related decisions. Some of the statements made by the IPF regarding the importance of forests to Indigenous peoples are as follows:

- recognizing that forests are fundamental to the survival of Indigenous peoples as distinct peoples, forming the basis for their livelihoods, cultures and spirituality;

- recognizing that the maintenance of cultural diversity and the welfare of Indigenous and forest-dependent peoples is a fundamental aspect of sustainable forest management;

Some of the general principles put forth by this committee are listed below:

- That the rights, welfare, viewpoints and interests of Indigenous and other forest-dependent peoples should be central to all decision-making about forests at local, national, regional and international levels.

- Their rights to their lands, territories, forests and other natural resources should be recognized, secured, respected and protected;

- Traditional forest-related knowledge is essential to sustainable forest management practices;

- All future international instruments and mechanisms dealing with forests should involve Indigenous and other forestdependent peoples in all stages of decision-making as equal partners.

There are several options available to both the federal and provincial governments which could include criteria set by Indigenous peoples and their full participation in resource management planning and use. One is a community-based approach to forest management, concurrent with a shift from large corporate tenures to community held tenures. Management goals and objectives would represent community interests, and empower communities to pursue an ecologically-based approach replacing economically driven policies with policies that effectively protect biodiversity and the integrity of the ecosystem (M'Gonigle 1997).

Co-management is another means of achieving a greater degree of input from Aboriginal communities, and a more holistic approach to ecosystem management. Many provinces are entering into co-management agreements in which Aboriginal communities are sharing limited management responsibilities in some areas of the traditional territories (Bombay 1996). These agreements have many forms. Some view co-management as a recognition of shared jurisdiction, and some as co-operative management in which the province maintains its jurisdiction over natural resources, with the Aboriginal community as simply a stakeholder working under the authority of the province (Bombay 1996). Forest licensees are also entering into joint ventures with Aboriginal communities. These joint ventures vary from full joint venture business partnerships, to working 
agreements for employment and capacity-building opportunities in which the Aboriginal community and licensee are jointly involved. However, in most of these joint venture/co-management initiatives the application of traditional knowledge is minimal (see Bombay 1996 for an exception). One of the greatest stumbling blocks to the incorporation of traditional knowledge in resource use and management planning is the lack of funding available for Aboriginal communities to collect the baseline data needed to document traditional patterns of travel and resource use.

\section{Implementation of Article 8(j) in Canada}

Canada has committed to the implementation of Article 8(j) of the CBD, and associated Articles 10(c), 17.2 and 18.4. This is being addressed through the creation of Canada's own domestic inter-sessional process that will coordinate related policy and legislative change in Canada. In addition, this process will establish a link between the activities of Aboriginal peoples from Canada in international policy-building and related policy-building in Canada.

The Working Group on Article 8(j) is an open-ended working group, supported by five national Aboriginal focal points, the Assembly of First Nations, the Inuit Circumpolar Conference, the Council of Aboriginal Peoples, the Metis National Council, and the Metis National Council of Women. The Working Group also includes federal government departments such as the Department of Indian and Northern Affairs, the Department of Justice, Industry Canada, Environment Canada, and the Department Fisheries and Oceans, and NGOs with particular interest in articles of the CBD of relevance to Indigenous peoples. The working group facilitates and coordinates the exchange of views and advice to the federal government regarding the implementation of Article 8(j) in Canada. However, very little incorporation of Article 8(j) into ecosystem management and planning has occurred.

\section{Where to go from here}

The CBD outlines several provisions that, if implemented, could provide for the equitable sharing of benefits resulting from use and application of traditional and Indigenous knowledge, innovations and practices. This would result in a strengthening of Indigenous and local communities, and the protection of biological diversity through sustainable use practiced by these communities. The Biodiversity Program of the International Union for the Conservation of Nature and Natural Resources (IUCN) commissioned a task force to develop meaningful partnerships with Indigenous peoples. The long-term goals include the development of stronger legal instruments to promote Indigenous rights, and the preparation of guidelines for "equitable sharing" related to sustainable use of biological resources and traditional lifestyles, as called for in the CBD. The Biodiversity Program of the IUCN commissioned work on Traditional Resource Rights (TRR) to investigate how international agreements on environment, trade and sustainable development could be harmonized with human rights to support and strengthen the role of Indigenous peoples in biodiversity conservation.

Although the CBD encourages the use and application of those "Indigenous and traditional technologies" that are relevant to biodiversity conservation, it does not provide the mechanisms needed to protect the rights of Indigenous peoples and local communities to their genetic materials, knowledge and technologies (Posey 1996). The TRR model developed by Posey
(1996) offers specific recommendations as to how Indigenous communities can be supported in their attempts to maintain, conserve, and establish their own programs and projects for biodiversity conservation, including integration of their priorities and criteria. The TRR concept can guide the development of sui generis systems which strengthen and empower Indigenous peoples in the protection of intellectual property and traditional resource rights. Some of the actions recommended by the TRR model are listed below:

1. National Strategies should ensure the full participation of Indigenous peoples and local communities in all aspects of conceptualisation, development, and implementation of national plans, strategies and programs; insist that special priority be give to conservation of Indigenous lands that are not degraded and develop pilot programs which are conceived and implemented by Indigenous peoples.

2. Implementation of CBD Article 8(j) should include land demarcation, support for Indigenous-based and designed conservation and sustainable development efforts, research centres to develop strategies and models to apply traditional technologies in a larger context, and supporting and strengthening Indigenous organizations.

3. Environmental Impact Assessments (EIAs) should include not only local guidance and full participation, but Indigenous criteria and mechanisms for assessment. Prior informed consent is fundamental, since Indigenous and traditional peoples must be afforded full disclosure of all relevant information regarding projects, including background, technical surveys, feasibility studies, existing and final assessments.

4. Develop "Standards of Best Practice" and "Codes of Conduct" for business and professional organisations, as well as for educational and research institutions, in collaboration with Indigenous and traditional peoples.

5. Identify additional funds and sources of funding for Indigenous peoples and local communities to support the maintenance and development of their own regimes to regulate access to, and control over, knowledge and resources, and to finance their own biological diversity and conservation efforts (e.g., community-controlled research).

The key to the success of this approach is to convince governments (both federal and provincial) and other stakeholders with a vested interest in the land that traditional knowledge is fundamental to effective conservation and sustainable management of forest resources. One assumption of the TRR model is that the best way to maintain biodiversity is through development of mechanisms to protect and enhance Indigenous, traditional and local communities. There is increasing recognition that use and application of traditional ecological knowledge and Indigenous natural resource management systems provides effective alternative strategies for conservation and sustainable use of natural resources. It is now up to First Nations and other Aboriginal groups to make the federal, provincial and territorial governments aware of their international commitments, and thus their national and local obligations to Indigenous peoples.

\section{References}

Barsh, R.L. and J.Y. Henderson. 1997. Biodiversity and Aboriginal Peoples. Prepared for the Native Law Center of Canada, University of Saskatchewan, Saskatoon, SK.

Bombay, H. 1996. Aboriginal forest-based ecological knowledge in Canada. Discussion paper. National Aboriginal Forestry Association. Ottawa, ON. 
M'Gonigle, M. 1997. Behind the Green Curtain. Alternatives Journal 23(4): 16-21.

Ministry of Forests. 1995. Biodiversity Guidebook. Victoria, BC. Posey, D.A. 1996. Traditional Resource Rights. International Instruments for Protection and Compensation for Indigenous Peoples and Local Communities. International Union of Conservation of Nature and Natural Resources.
World Commission on Environment and Development. 1987. Our Common Future. Oxford University Press, Walton Street, Oxford. 